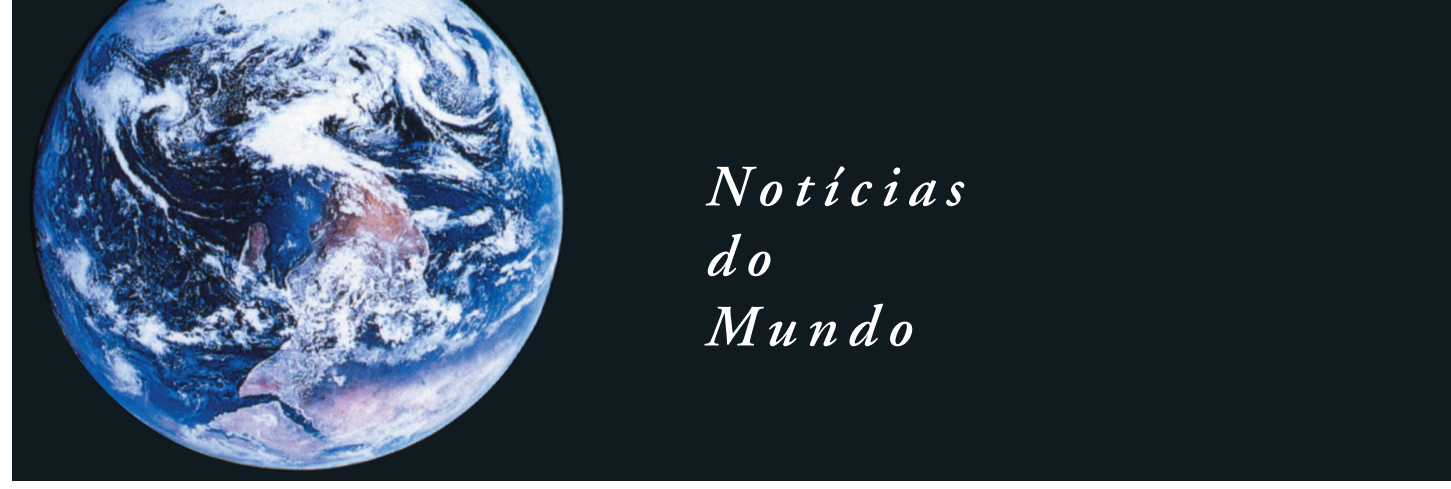

também estão ao alcance de quase qualquer indivíduo".

O guia deixa claro que não se trata de um manifesto antidrone, porque tais equipamentos podem ser úteis para a sociedade, mas traz instruções para que as pessoas saibam se defender de um eventual uso abusivo. 0 pesquisador Pablo de Soto explica, em artigo na revista Teknocultura (vol.12, no3, 2015) que a ideia do projeto é promover o uso de drones como uma tecnologia social. Para isso, suas ações envolvem, além do guia, a criação de um veículo aéreo não tripulado, batizado de Flone, construído com hardware e software livres, e a realização de uma cartografia aérea da Vila Autódromo, uma comunidade local do Rio de Janeiro que resiste à expulsão em uma área anexa à construção do Parque Olímpico.

Falar sobre drones e pensar sobre sua utilização, a se julgar pelos números, se mostra cada vez mais necessário. Se a projeção da Admistração Federal dos Estados Unidos (AFA) se concretizar, até 2020 serão sete milhões de drones voando somente pelos céus do país. De acordo com a agência Lusa, será o triplo do número que se espera estar em circulação no final de 2016.

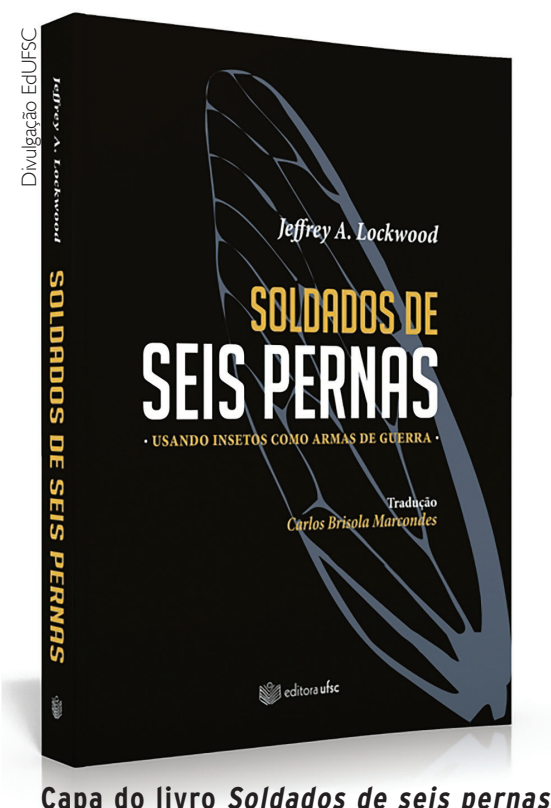

RESENHA

\section{Soldados de seis pernas}

Jáimaginou umabombadeabelhas? $\mathrm{Ou}$ insetos criados especialmente para disseminar doenças? Ou ainda pragas controladas para destruir plantações de nações inimigas? De acordo com Jeffrey Lockwood, entomólogo e professor do Departamento de Ciências Naturais e Humanidades da Universidade do Wyoming, Estados Unidos, isso não é apenas imaginação, mas uma assustadora realidade. Em seu livro Soldados de seis pernas: usando insetos como armas de guerra, ele conta a história ainda pouco conhecida da utilização de insetos como armas de guerra e instrumentos de tortura e terror. Publicado originalmente pela Oxford University Press e lançado no Brasil no ano passado pela Editora da Universidade Federal de Santa Catarina (EdUFSC), o livro já recebeu dois prêmios literários: a Medalha John Burroughs e o Pushcart Prize.

Lockwood analisou de forma exaustiva documentos históricos e arquivos militares em busca de material para compor seu livro. $\mathrm{O}$ resultado é um relato bem documentado e assombroso sobre como simples insetos podem se tornar verdadeiras armas de destruição.

ARMAS DE GUERRA Insetos são utilizados como arma há séculos. O relato de Soldados de seis pernas começa no paleolítico e chega aos dias atuais. Os primeiros registros de guerras narram a utilização de abelhas e vespas para desorientar exércitos inimigos. Na Idade Média, exércitos catapultavam colmeias de abelhas sobre os muros de cidades cercadas. Em 1942, bombardeiros japoneses lançaram recipientes de cerâmica cheios de vetores de cólera sobre cidades no sul da China, fazendo mais de 200 mil vítimas. Em 1960, estrategistas norte-americanos produziram mensalmente 130 milhôes de mosquitos portadores do flavivírus com o objetivo de disseminar a febre 
